\title{
Subsurface seeding of surface harmful algal blooms observed through the integration of autonomous gliders, moored environmental sample processors, and satellite remote sensing in southern California
}

\author{
Bridget N. Seegers, ${ }^{* 1}$ James M. Birch, ${ }^{2}$ Roman Marin III, ${ }^{2}$ Chris A. Scholin, ${ }^{2}$ David A. Caron, ${ }^{1}$ \\ Erica L. Seubert, ${ }^{1}$ Meredith D. A. Howard, ${ }^{3}$ George L. Robertson, ${ }^{4}$ Burton H. Jones ${ }^{1,5}$ \\ ${ }^{1}$ Department of Biological Sciences, University of Southern California, Los Angeles, California \\ ${ }^{2}$ Monterey Bay Aquarium Research Institute (MBARI), Moss Landing, California \\ ${ }^{3}$ Biogeochemistry Department, Southern California Coastal Water Research Project, Costa Mesa, California \\ ${ }^{4}$ Ocean Monitoring Program, Orange Country Sanitation District, Fountain Valley, California \\ ${ }^{5}$ Red Sea Research Center, King Abdullah University of Science and Technology, Thuwal, Kingdom of Saudi Arabia
}

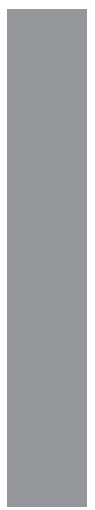

\begin{abstract}
An observational study was performed in the central Southern California Bight in Spring 2010 to understand the relationship between seasonal spring phytoplankton blooms and coastal processes that included nutrient input from upwelling, wastewater effluent plumes, and other processes. Multi-month Webb Slocum glider deployments combined with MBARI environmental sample processors (ESPs), weekly pier sampling, and ocean color data provided a multidimensional characterization of the development and evolution of harmful algal blooms (HABs). Results from the glider and ESP observations demonstrated that blooms of toxic Pseudo-nitzschia sp. can develop offshore and subsurface prior to their manifestation in the surface layer and/or near the coast. A significant outbreak and surface manifestation of the blooms coincided with periods of upwelling, or other processes that caused shallowing of the pycnocline and subsurface chlorophyll maximum. Our results indicate that subsurface populations can be an important source for "seeding" surface Pseudo-nitzschia HAB events in southern California.
\end{abstract}

Coastal continental shelf regions are areas of high ocean primary production and efficient energy transfer to higher trophic levels, contributing to their ecological and economical value. These shelf regions are also vulnerable to harmful algal blooms (HABs), which are defined as significant increases in phytoplankton biomass with harmful consequences such as toxin production or the accumulation of biomass that negatively impacts food-web dynamics and ecosystem structure. Globally, the occurrence of HABs has been increasing for decades accompanied by longer bloom duration and increased toxicity (e.g., Hallegraeff 1993). The diatom Pseudo-nitzschia, a predominant HAB genus of concern, produces the neurotoxin domoic acid (DA) that threatens the health of humans and wildlife from invertebrates to marine mammals and birds. Further details on Pseudo-nitzschia, including its physiology, toxicity, and global impacts of toxic events, have been thoroughly summarized in reviews by Anderson et al. (2012), Lelong et al. (2012), and Trainer et al. (2012).

*Correspondence: seegers@usc.edu
The negative ecological and economic impacts of HABs have resulted in a desire for increased understanding of the physical, chemical, and biological variables influencing their success in natural phytoplankton communities. Many HAB events are studied opportunistically or have limited synoptic sampling, resulting in an inability to resolve the bloom initiation and subsequent evolution. In addition, HAB research often relies on remote sensing and surface sampling and, therefore, limits observations to the near-surface region. A fundamental drawback of this approach is that it visualizes only a fraction of the water column and the euphotic zone. In the Southern California Bight (SCB), much focus has been given to the upwelling nutrient dynamics influence on HABs (Kudela et al. 2005, 2010; Pitcher et al. 2010). A variety of predictive models that typically rely on nutrient concentrations and ratios, temperature, mixed layer depth, and stratification strength have been developed to better understand the conditions under which Pseudo-nitzschia blooms develop, but these models have had limited predictive power (e.g., Lane et al. 2009; Anderson et al. 2011). The models often focus on the availability of upwelled nutrients in surface waters to support growth and accumulation of the surface 
phytoplankton community into blooms. The models tend to overlook subsurface phytoplankton communities that are upwelled along with the nutrients into the surface layer and affect surface plankton community composition and bloom initiation. Unfortunately, much of the subsurface structure and dynamics are often missed by standard monitoring methods.

Studies have shown that HABs can be entrained into surface water masses that can advect cells great distances both along shore and cross-shelf. Trainer et al. (2002) and MacFadyen et al. (2008) documented this transport of Pseudonitzschia and its impact on coastal waters along the Washington coast. More recently, the importance of subsurface thin layers as a source for surface HAB events was hypothesized as an explanation for the sudden appearance of HAB species and events (Rines et al. 2002; McManus et al. 2008). Tilstone et al. (2000) showed that Iberian upwelling could transport diatoms on the shelf and Crespo et al. (2007) suggested that surface currents could then transport the diatoms. Field observations have shown the potential importance of upwelling transport of subsurface dinoflagellate populations to initiate and maintain surface blooms (e.g., Tyler and Seliger 1978; Pitcher et al. 1998, 2010). Modeling results have also shown wind-driven subsurface Ekman flow could move subsurface phytoplankton population into surface layers initiating blooms (Janowitz and Kamykowski 2006), yet these types of movements and initiation events have been unobserved for diatoms.

The goal of this effort was to better understand the onset and connections between subsurface and surface blooms of the toxic diatom, Pseudo-nitzschia, off the southern California coast. Toxic blooms of Pseudo-nitzschia are a recurring problem in this area with some of the highest DA concentrations per cell reported for natural populations (Schnetzer et al. 2007, 2013). San Pedro Bay, in the central SCB, is strongly influenced by both anthropogenic urban inputs and coastal upwelling, both of which can contribute to phytoplankton blooms and $\mathrm{HAB}$ events. Major sources of anthropogenic nutrients in this region include two ocean outfall diffusers operated by the Orange County Sanitation District (OCSD) and the Los Angeles County Sanitation District and three channelized riverine sources (Los Angeles River, San Gabriel River, Santa Ana River). Wastewater effluent from the subsurface outfalls contains concentrations of nitrogen and phosphorus that are up to three orders of magnitude greater than maximal ambient nutrient concentrations, and the buoyant effluent plumes also entrain deeper, nutrient enriched, sub-nutricline water as they rise to their equilibrium depth. These nutrient fluxes contribute significantly to total nutrient budgets in this coastal region (Howard et al. 2014), and therefore, may contribute to the growth of subsurface populations of Pseudo-nitzschia.
This project combined multi-month glider deployments, mooring and pier phytoplankton community composition and temperature data, and remotely sensed satellite ocean color and temperature data, which allowed for the monitoring of conditions associated with the evolution of a Pseudo-nitzschia bloom from onset to demise. The moored environmental sample processors (ESPs) confirmed an offshore subsurface population of Pseudo-nitzschia and the glider data showed that upwelling moved the subsurface plankton communities into the surface waters, which resulted in a Pseudo-nitzschia bloom and demonstrated for the first time that upwelled subsurface phytoplankton populations can initiate HABs in the region.

\section{Methods}

The study was conducted in the central SCB with a focus on the San Pedro Channel, near the Los Angeles Harbor (Fig. 1). The San Pedro Channel provides us with a unique environment to study the seasonal variation in phytoplankton

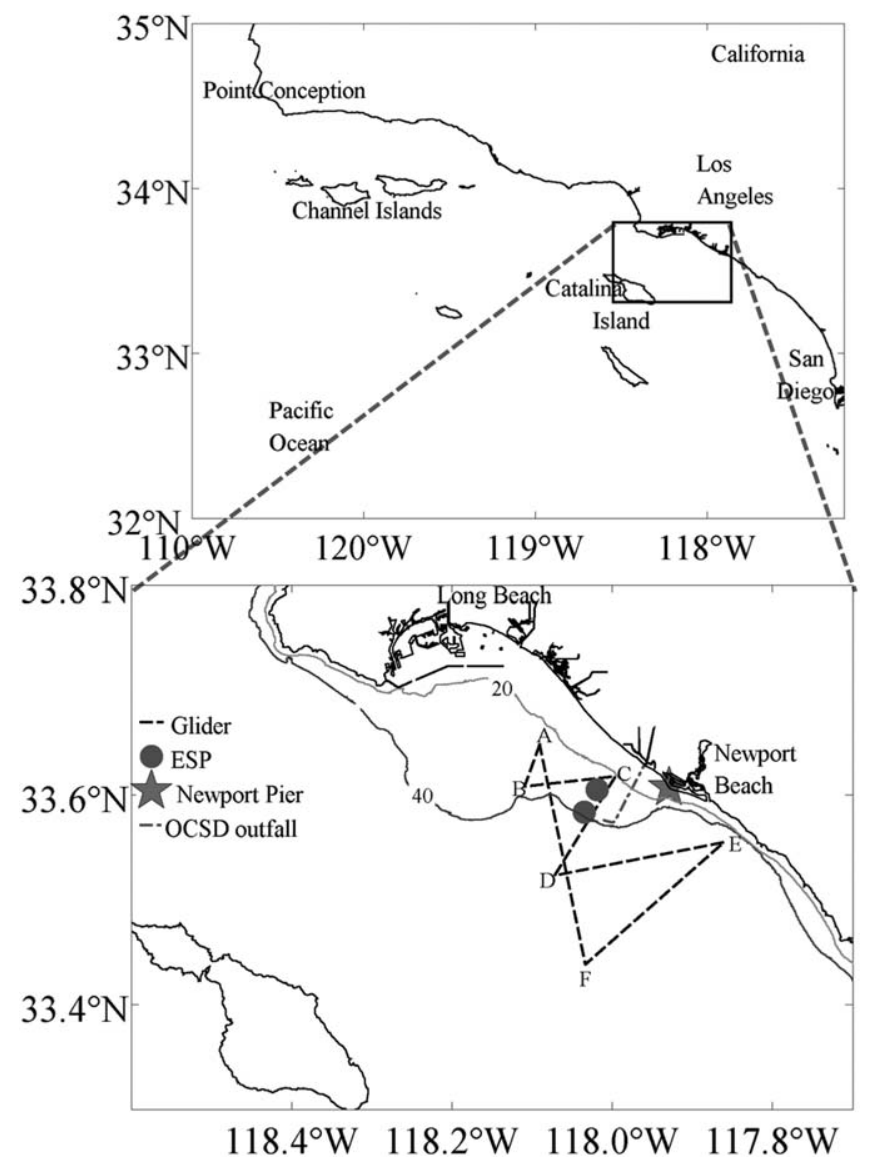

Fig. 1. Map of the $S C B$ and the small rectangle marks the study area (top). Lower planel shows the Central SCB, San Pedro Channel, with locations of the glider track indicated by the dashed line pattern, the MBARI EPS mooring locations by the gray circles, the Newport Pier by the gray star, and the OCSD outfall pipe north by the dash-dot lines. The letters $(\mathrm{A}-\mathrm{F})$ on the glider pattern indicate turning points and are used to clarify glider transect locations throughout the manuscript. 
blooms related to a variety of processes including nutrient inputs from coastal upwelling, river runoff, and treated sewage effluent plumes, and other coastal processes.

\section{Equipment and sampling \\ Webb Slocum Glider}

A major goal of the research was to observe the coastal ocean before, during, and after $\mathrm{HAB}$ events with a particular focus on signs of $\mathrm{HAB}$ population advection into the surface water from the subsurface. Webb Slocum G1 shallow-water gliders were used to provide spatial mapping of key variables over an extended period of time, and data transferred from the gliders were used in the decisional process for triggering opportunistic sampling (e.g., ship sampling). A glider was deployed continuously during the spring of 2010 from late February through mid-June, a time window when upwelling tends to be most intense in the region. The glider ran a zigzag pattern in the San Pedro Bay on and off the shelf (Fig. 1). The glider dove in a sawtooth pattern three meters from the surface to four meters from the bottom on the shelf or to a depth of $100 \mathrm{~m}$ off the shelf. The glider was equipped with a SeaBird conductivity-temperature-depth sensor (SBE-41cp CTD), a GPS, Iridium communications enabling daily data transmission, and WET labs ECO pucks optical instruments. The optical sensors included three fluorometers with excitation/ emission channels that measured chlorophyll $a$ (Chl a) $(470 \mathrm{~nm} / 695 \mathrm{~nm})$, colored dissolved organic matter $(370 \mathrm{~nm} /$ $460 \mathrm{~nm}$ ) and phycoerythrin/ rhodamine (540 nm/570 nm), and an optical backscatter sensor at three wavelengths.

The glider recoveries occurred approximately every three weeks throughout the deployment period and were based from the University of Southern California's Wrigley Institute for Environmental Studies on Catalina Island, where cleaning, calibrations, and battery change could occur quickly, thereby minimizing data gaps. The frequent recovery and maintenance helped to reduce biofouling on the sensors. The glider chlorophyll fluorometer was calibrated pre- and post-deployment using a serial dilution of a local mixture of cultured phytoplankton species (Cetinić et al. 2009). These measurements allowed us to monitor for longterm stability of the sensors and for effects of biofouling. A mix culture calibration does not ensure a representative chlorophyll concentration for all in situ phytoplankton communities encountered but was implemented to help reduce any biases. Glider chlorophyll concentrations often show a diel cycle mainly in the surface $4 \mathrm{~m}$ to $20 \mathrm{~m}$ (Davis et al. 2008), which is largely attributed to nonphotochemical quenching (Kiefer 1973). No corrections were made for quenching, because we were more interested in temporal and spatial patterns than the exact chlorophyll concentration and the values reported should only be considered very approximate values.

The glider did not have nutrient sensors, but nutrients and temperature are well correlated in the SCB and the nutricline in the southern California region has long been associated approximately with the $13^{\circ} \mathrm{C}$ isotherm (Armstrong and LaFond 1966). Therefore, we used temperature to roughly estimate the depth of the nutricline in the water column. Additionally, the temperature proxy can be used as an indicator for the appearance of nutrient-rich upwelled waters shoaling into the surface layer. Regional and seasonal-specific temperature to nutrient relationships have been developed using the nutrient data set from CalCOFI's (California Cooperative Oceanic Fisheries Investigations) southern California seasonal transects (Todd et al. 2009; Lucas et al. 2011). We used the CalCOFI 2010 winter and spring cruise data from the San Pedro Bay study region to develop a 2010 specific nutrient and temperature relationship for the glider deployments. Temperature was used as opposed to density as a nutrient proxy, because some of the analyzed data sets had only temperature available.

\section{Barnacle domoic acid}

Gooseneck barnacles (order Pedunculata) often covered the glider following three or more weeks of deployment. These barnacles were collected and stored in Falcon ${ }^{\circledR}$ tubes at $-20^{\circ} \mathrm{C}$ until analyzed for DA by enzyme-linked immunosorbent assay (ELISA) by Mercury Science (Durham, NC). A minimum of one gram of whole barnacles were sonicated in $3 \mathrm{~mL}$ of $10 \%$ methanol until the body tissues were liquefied, typically between $30 \mathrm{~s}$ and $60 \mathrm{~s}$. Samples were centrifuged for $10 \mathrm{~min}$ at $4000 \mathrm{rpm}$, the supernatant was diluted with the sample dilution buffer provided by the manufacturer and the resulting detection limit was $0.005 \mu \mathrm{g}$ domoic acid $/ \mathrm{g}$ body weight. The accuracy of the ELISA for DA analysis in shellfish tissues has been validated and the assay gives results equivalent to those acquired by standard high performance liquid chromatography (Litaker et al. 2008).

\section{Environmental sample processors (ESPs)}

Two ESPs were deployed at fixed points in the San Pedro Channel from 2 April to 28 April for in situ measurements of temperature, potentially toxic algal species and concentrations of particulate DA (Fig. 1). The ESP is an electromechanical device that filters seawater and either archives the filtrate for later analysis, or performs a variety of analytical tests on board the instrument. For this deployment, the instruments were configured to detect several species of Pseudo-nitzschia and other HAB targets groups using DNA probes targeted to sequences in the large subunit of the ribosomal gene (Scholin et al. 1997; Greenfield et al. 2006). The probes work via a sandwich hybridization array (SHA), resulting in spots of varying intensity depending on target concentration. The presence and relative abundances of HAB species were estimated from the intensity of probe spots on a filter membrane relative to filter background as measured by a charge coupled device (CCD) camera (Greenfield et al. 2008). In this deployment, we were unable to create standard curves that would assign cell abundances to spot 


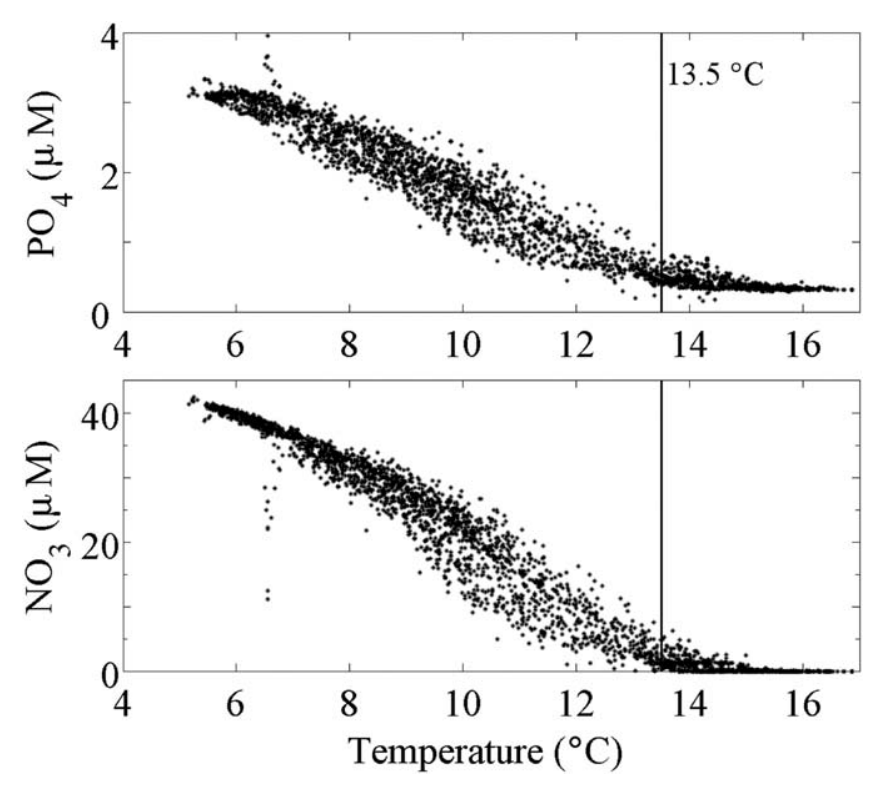

Fig. 2. The temeperature vs. $\mathrm{PO}_{4}$ and $\mathrm{NO}_{3}$ concentrations from the 2010 CalCOFI winter and spring cruises data sets in the Central SCB. The solid, vertical black line indicates $13.5^{\circ} \mathrm{C}$.

intensity and, thus, report only trends in diatom abundances. DA concentrations on the ESPs were measured throughout the deployment by competitive ELISA (Doucette 2009). The ESPS were also equipped with a CTD. The ESP's were moored near the glider transect off of Huntington Beach suspended at an average depth of $\sim 17 \mathrm{~m}$ in an attempt to sample the subsurface chlorophyll maximum. One ESP ("ESPnearshore") was moored $4 \mathrm{~km}$ from shore at the $30 \mathrm{~m}$ isobaths $\left(33^{\circ} 36.373^{\prime} \mathrm{N}, 118^{\circ} 1.284^{\prime} \mathrm{W}\right)$. The second ESP ("ESPoffshore") was placed $7 \mathrm{~km}$ from shore at the $60 \mathrm{~m}$ isobath $\left(33^{\circ} 35.125^{\prime} \mathrm{N}, 118^{\circ} 2.248^{\prime} \mathrm{W}\right)$ (Fig. 1).

\section{Moderate Resolution Imaging Spectroradiometer (MODIS)}

Level 3 Aqua MODIS sea surface temperature (SST) and chl a concentration data with $0.0125^{\circ}$ pixel resolution obtained from the West Coast Regional Node of National Oceanic and Atmospheric Administration (NOAA) CoastWatch were analyzed throughout the glider deployment to monitor for surface manifestations of algal blooms. Linking these data from near-surface measurements (provided by satellite imagery) and subsurface measurements (provided by gliders) provided a three-dimensional perspective of bloom development, propagation, and density.

\section{Newport pier surface data}

The data collected during this project was enriched with data from the Southern California Coastal Ocean Observing System (SCCOOS). SCCOOS provides a weekly service of $\mathrm{HAB}$ species sampling from six piers including Newport Pier in our sampling area. The weekly Pseudo-nitzschia counts are separated into Pseudo-nitzschia delicatissima and seriata groups and we report the total Pseudo-nitzschia abundance. This ongoing pier monitoring (www.sccoos.org) encompassed several variables including $\mathrm{HAB}$ species, discrete surface chlorophyll concentration, discrete surface particulate DA (pDA) with a limit of detection of $0.1 \mu \mathrm{g} \mathrm{L}^{-1}$ and continuous temperature.

\section{Upwelling index}

Conditions conducive to coastal upwelling in the region were monitored using the Pacific Fisheries Environmental Laboratory (PFEL) upwelling index (UI) calculated from the intensity of upwelling-favorable wind for the southern California location at $33^{\circ} \mathrm{N}, 119^{\circ} \mathrm{W}$, approximately $100 \mathrm{~km}$ offshore to the southwest from the study area, and data were obtained from PFEL website (http://www.pfeg.noaa.gov/). The offshore water transport estimates $\left(\mathrm{m}^{-3} \mathrm{~s}^{-1}\right.$ per $100 \mathrm{~m}$ of coastline) were calculated every six hours and daily averaged UI were available.

\section{Results}

The CalCOFI 2010 winter and spring nutrient data overlapped with the glider deployment revealing that there was a steady increase in nitrate and phosphate concentrations with decreasing temperature starting at $13.5^{\circ} \mathrm{C}$ (Fig. 2). The 2010 seasonal-specific information was used to confirm the appropriateness of the $13.5^{\circ} \mathrm{C}$ isotherm to estimate the nutricline depth and to roughly approximate the initial appearance of shoaling nutrient-rich waters into the surface layer.

Compared with other reported observations from the region (Schnetzer et al. 2007, 2013), the 2010 spring deployment season was a relatively uneventful HAB year in the SCB (Seubert et al. 2013). However, a large Pseudo-nitzschia bloom followed a pair of two-day upwelling events that occurred five days apart in late April. The first upwelling episode occurred on 20 April and 21 April, when the daily UI rose above $300 \mathrm{~m}^{-3} \mathrm{~s}^{-1}$ per $100 \mathrm{~m}$ of coastline. A five-day lull in the winds from 22 April to 27 April followed, when the UI dropped to $2 \mathrm{~m}^{-3} \mathrm{~s}^{-1}$ per $100 \mathrm{~m}$ of coastline before upwelling-favorable winds returned on 28 April, when the UI again rose to more than $300 \mathrm{~m}^{-3} \mathrm{~s}^{-1}$ per $100 \mathrm{~m}$ of coastline. Surface temperatures at Newport Pier responded to the upwelling-favorable conditions with a corresponding decrease from near $18^{\circ} \mathrm{C}$ on 17 April to below $13^{\circ} \mathrm{C}$ on 22 April followed by a brief warming after which temperatures again decreased below $13^{\circ} \mathrm{C}$ on 30 April (Fig. 3). Surface chlorophyll concentrations at the Newport Beach Pier increased from $1 \mu \mathrm{g} \mathrm{L}^{-1}$ on 12 April to $11.4 \mu \mathrm{g} \mathrm{L}^{-1}$ on 26 April (not shown), and the total Pseudo-nitzschia abundance increased from undetected prior to the wind event to $1.30 \times$ $10^{4}$ cells $\mathrm{L}^{-1}$ on 26 April and increased to nearly $2.80 \times 10^{4}$ cells $\mathrm{L}^{-1}$ a week later on 3 May (Fig. 3).

The two ESPs detected cooling of the surface waters due to the 20 April upwelling event along with an increase in $P$. multiseries/pseudodelicatissima probe signal (Fig. 3). At the 


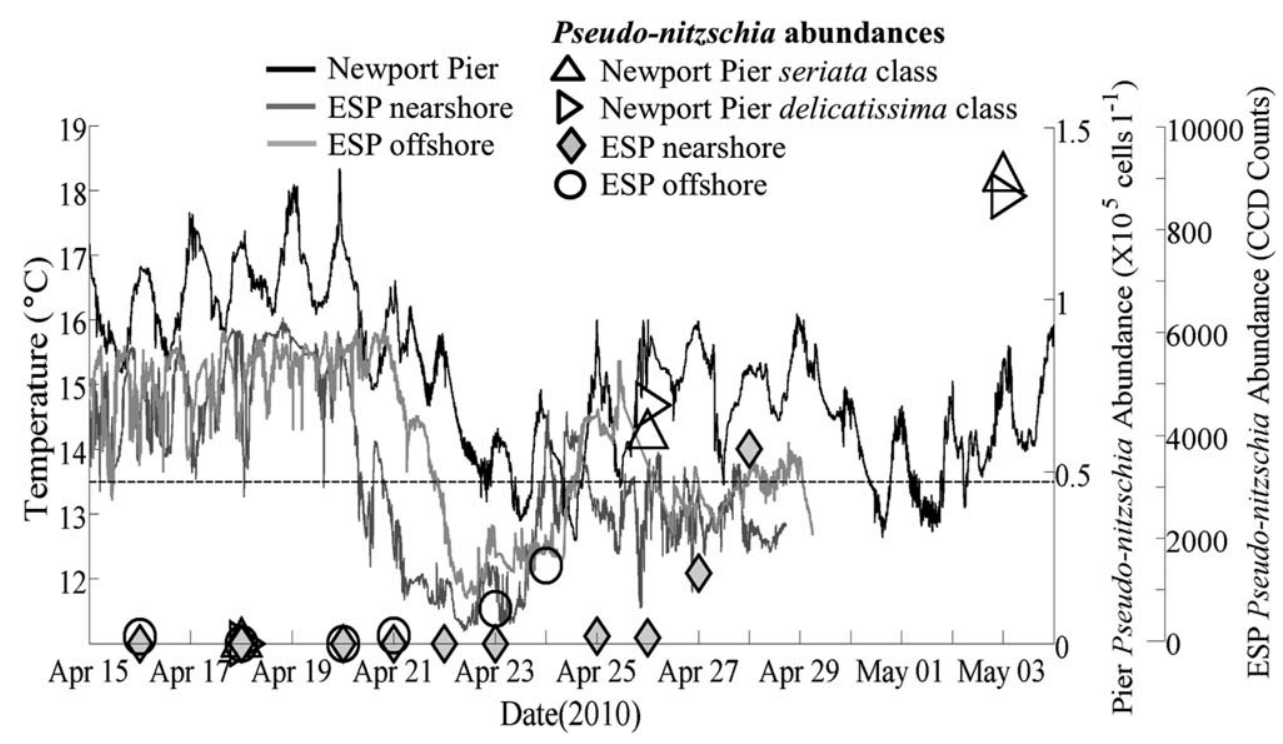

Fig. 3. The times series of Newport Pier automated pier station surface temperature and subsurface ESP CTD temperature data. The $13.5^{\circ} \mathrm{C}$ is indicated by the horizontal dashed line. Pseudo-nitzschia abundances from discrete weekly surface samples at Newport Pier are shown separated into seriata class and delicatissima class. The ESP SHA probes produced CCD values for combined $P$. multiseries/pseudodelicatissima and $P$. australis relative abundance at ESPnearshore and ESPoffshore. All Pseudo-nitzschia abundances are below detection 18 April.

onset of upwelling, the ESPs were moored just above the subsurface chlorophyll maximum based on glider and boat observations. Although suspended at the same depth and moored only three kilometers apart, the two ESPs experienced the upwelling response at distinctly different times, as indicated by the temporal patterns of temperature and Pseudo-nitzschia counts. ESPnearshore, four kilometers from shore, experienced a sharp decrease in temperature from $15.5^{\circ} \mathrm{C}$ to $<12^{\circ} \mathrm{C}$ on 20 April and began to warm on 23 April as the upwelling relaxed (Fig. 3). Pseudo-nitzschia was not observed at ESPnearshore until after the upwelling on 25 April and the population showed a steady increase until the ESPs were removed on 28 April. ESPoffshore experienced a shorter period of cooling and the temperature dipped below $12^{\circ} \mathrm{C}$ only for only a single day on 21 April (Fig. 3). The appearance of $P$. multiseries/pseudodelicatissima coincided with the initial cooling at ESPoffshore on 21 April and steadily increased until the ESP stopped sampling on 24 April (Fig. 3).

The glider was removed 19 April to 23 April for calibrations and, therefore, glider data begins on 23 April and captures the second late-April upwelling event (Fig. 4). The glider observations show upward tilting of isotherms (Fig. 4A) and chlorophyll isopleths (Fig. 4B) toward the coast and into the surface waters revealing connectivity between the subsurface and surface communities. The $13.5^{\circ} \mathrm{C}$ isotherm indicating the estimated temperature intercept for the top of the nutricline reached the surface accompanied by elevated chlorophyll and the elevated chlorophyll was sustained in the surface layer (Fig. 4D). The upwelling event marked by the tipping isotherms was short lived and gliders observed subsequent shoreward advection of the $13.5^{\circ} \mathrm{C}$ isotherm and sinking of the nearshore chlorophyll maximum on 3 May, which led to the reestablishment of a subsurface chlorophyll maximum where the subsurface chlorophyll concentration was higher after the upwelling event than prior to the event (Fig. 4E,D). The glider data revealed significant temporal and spatial complexity including the occurrence of internal waves affecting cross-shelf patterns (not shown). The glider observations demonstrated continuity between the subsurface and surface layers during the upwelling event and subsequent relaxation (Fig. 4).

The three glider deployments provided sufficient barnacle biomass from the glider exterior for measurements of DA in the barnacle tissue. The barnacle tissue always tested positive for DA ranging from $0.32 \mu \mathrm{g} \mathrm{g}^{-1}$ to $1.75 \mu \mathrm{g} \mathrm{g}^{-1}$ (Table 1). The harvested glider barnacles tested positive for DA even when the weekly nearshore pier surface samples detected no DA or Pseudo-nitzschia.

MODIS SST and chlorophyll images show regional change associated with the late April upwelling event. On 19 April, SST in the San Pedro Channel ranged from $16^{\circ} \mathrm{C}$ to $17^{\circ} \mathrm{C}$ (Fig. 5A) and elevated chlorophyll concentrations ranging from $2 \mu \mathrm{g} \mathrm{L}^{-1}$ to $10 \mu \mathrm{g} \mathrm{L}^{-1}$ were found within two kilometers of the coast (Fig. 5B). On 24 April, the regional SST had cooled $1^{\circ} \mathrm{C}$ to $3^{\circ} \mathrm{C}$ with the most dramatic cooling nearshore where temperatures had dropped to $13.5^{\circ} \mathrm{C}$ due to upwelling (Fig. 5C). MODIS chlorophyll imagery provides an effective view of the spatial extent of surface phytoplankton concentrations. Chlorophyll concentrations on 24 April were greater than $10 \mu \mathrm{g} \mathrm{L}^{-1}$ throughout the nearshore region (Fig. 5D). Both the glider chlorophyll fluorescence 


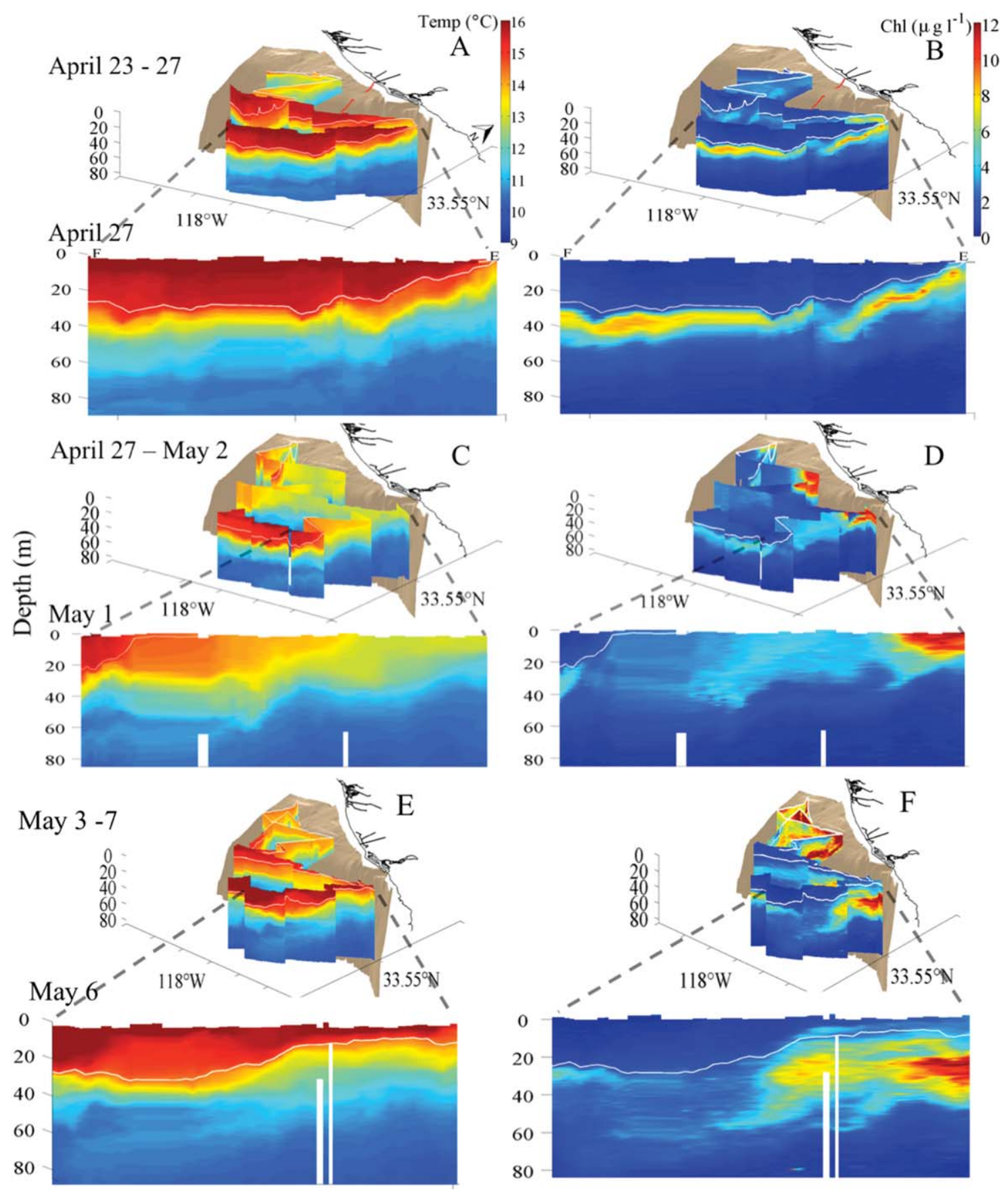

Fig. 4. San Pedro Bay regional glider time series showing (A, C, E) temperature and (B, D, F) chlorophyll fluorescence from 23 April to 7 May. For each time period, the top image in each panel shows the curtian plot of the region and the lower image is the southernmost transect rotated to display as a flat section (line EF details Fig. 1). The white line is the $13.5^{\circ} \mathrm{C}$ isotherm, a proxy for the top of the nutricline. The tan areas indicate bottom topography. The red lines extending along the bottom from the coast show the location of the OCSD outfall pipe.

and satellite chlorophyll show elevated surface chlorophyll concentrations close to the coast. The combined images demonstrate continuity between the high chlorophyll region at the surface close to the coast and deepening into the subsurface chlorophyll maximum away from the coast.
The combined glider and MODIS chlorophyll pattern verified that the high nearshore MODIS chlorophyll was not an artifact resulting from either elevated suspended particle concentrations that characterize Case 2 waters, or land effects (Fig. 5E). 
Table 1. DA concentrations from barnacles collected from the exterior of the glider throughout glider deployments.

\begin{tabular}{lcc}
\hline $\begin{array}{l}\text { Deployment- } \\
\text { Recovery Date }\end{array}$ & $\begin{array}{c}\text { Barnacles } \\
\text { weight }(\mathbf{g})\end{array}$ & $\begin{array}{c}\text { Barnacle tissue } \\
\text { DA concentration } \\
\left(\mu \mathbf{g ~ g}^{-1}\right) \pm \mathbf{s d}\end{array}$ \\
\hline 24 March-19 April & $2.16(2$ samples $)$ & $0.32 \pm 0.05$ \\
23 April-19 May & $1.80(1$ sample $)$ & 1.75 \\
24 May-17 June & $0.32(1$ sample $)$ & 0.44 \\
\hline
\end{tabular}

\section{Discussion}

The development, establishment, and dissipation of a $\mathrm{HAB}$ event were observed through a combination of glider observations, pier sampling, ESPs, and satellite ocean color imagery. The continuity between the subsurface phytoplankton community and the surface community during an upwelling event suggests that upwelling both transported nutrient-rich waters and seeded $\mathrm{HAB}$ populations into the surface waters, resulting in an intensified and sustained bloom event.

A bloom resulting from a nutrient-rich upwelling event is not surprising, but the demonstrated subsurface phytoplankton population seeding of a surface bloom was new. Seasonal upwelling brings deep nutrient-rich waters to the surface waters providing nutrients to support blooms. Nutrients must be available to support high levels of primary production that support HABs, but nutrients alone do not tell the story. Our results revealed a direct connection between subsurface and surface populations at the time of the
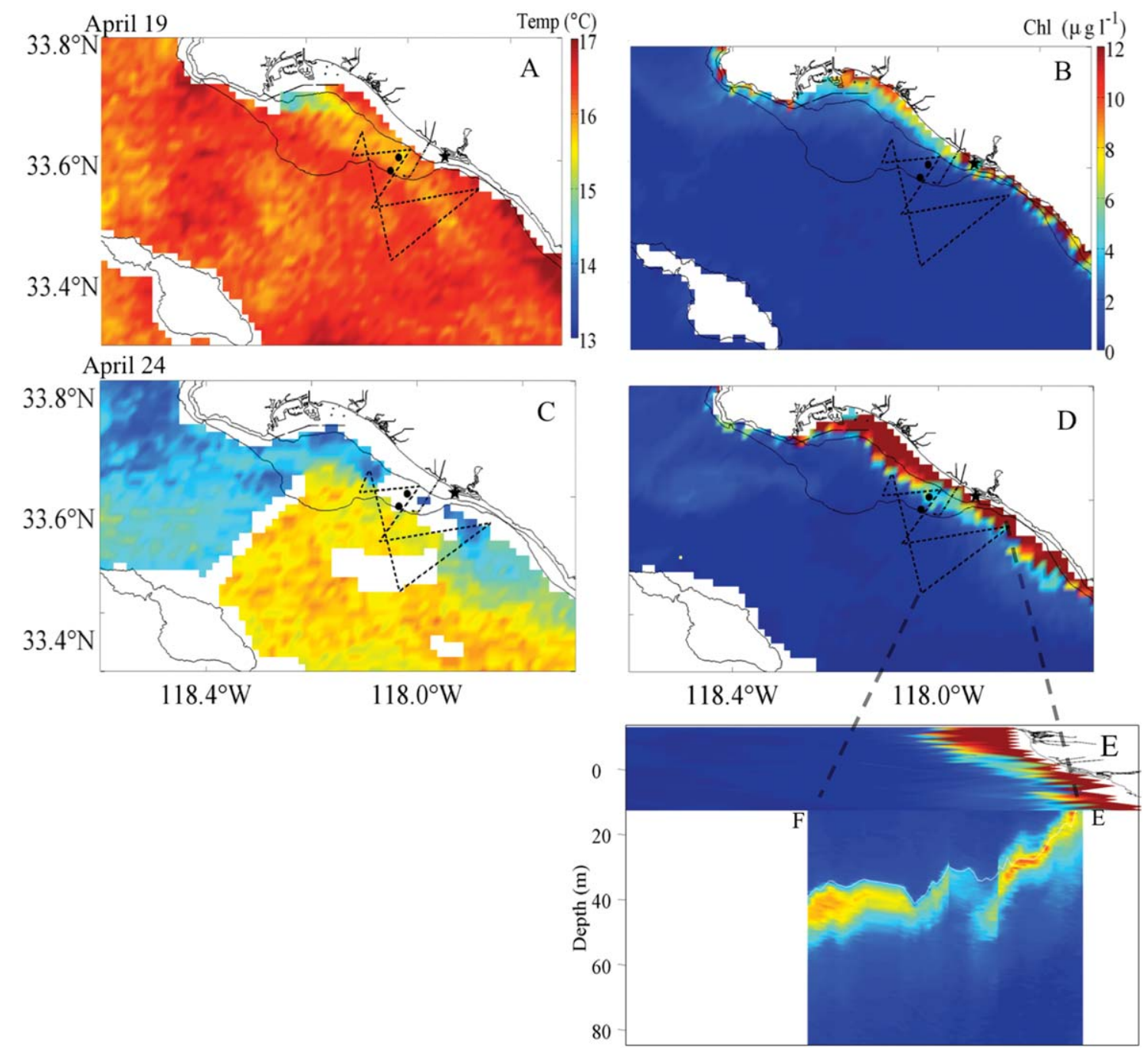

Fig. 5. MODIS images of SST (A, C) and chl $a(D, E)$ from San Pedro Bay for 19 April and 24 April. The glider track and the OCSD outfall are indicated by dashed black lines, black dots indicate ESP mooring locations and the Newport Pier is indicated by the star symbol. (Details in Fig. 1). Panel E shows the MODIS chlorophyll image overlaid three-dimensionally on the southernmost glider transect, line E-F, from 27 April demonstrating the continuity between subsurface and surface phytoplankton communities, as well as the consistency between and in situ and remotely sensed chlorophyll. 
appearance of the surface bloom, indicating that subsurface populations could influence surface community composition by seeding the surface outbreaks. The existence of a subsurface offshore Pseudo-nitzschia population was confirmed by the ESP results and the connection of the subsurface phytoplankton populations to the surface was shown by the glider observations.

The initiation of the observed surface bloom event through advection is further supported, because the rate of population increase of Pseudo-nitzschia was much greater than could be explained solely by cell division. If the bloom was simply a growth rate response to the influx of nutrientrich upwelled waters on 23 April, then a growth rate of about $1.8 \mathrm{day}^{-1}$, which exceeds maximum observed growth rates in the region, would be necessary to increase the Pseudo-nitzschia surface population in four days from below the detection limit of 2600 cells $\mathrm{L}^{-1}$ to the observed $1.4 \times$ $10^{5}$ cells $\mathrm{L}^{-1}$ for Pseudo-nitzschia seriata and delicatissima classes combined on 26 April. The species $P$. multiseries and $P$. australis, common along the California coast, have reported growth rates for cultures of 0.3-0.9 day $^{-1}$ depending on species, strain, light intensity, and nitrogen source (Hillebrand and Sommer 1996; Howard et al. 2007; Auro and Cochlan 2013). Reported growth rates of natural populations during short incubations are from 0.88 day $^{-1}$ to 1.19 day $^{-1}$ (Howard et al. 2007). Therefore, growth rate alone is unlikely to account for the quick increase in Pseudo-nitzschia population.

DA results from the barnacles support the persistence of a subsurface population of toxic Pseudo-nitzschia. Tissue samples from barnacles that grew on the gliders during deployments contained low levels of DA, indicative of the presence of the Pseudo-nitzschia throughout much of the year in the area where the glider was deployed. The barnacles harvested from the glider contained DA even when the weekly nearshore pier surface samples detect no DA or Pseudo-nitzschia. Although the ELISA results do not identify exactly when and where the DA was encountered, positive results confirmed that during the glider deployment the barnacles encountered DA-laden Pseudo-nitzschia.

Subsurface seeding populations influencing surface blooms has long been theorized as an important mechanism (Wilkerson and Dugdale 1987), but research efforts have not focused on the subsurface seeding mechanism for initiating Pseudo-nitzschia events. Thorough reviews of Pseudo-nitzschia and a variety of parameters affecting Pseudo-nitzschia blooms, growth, and toxicity by Lelong et al. (2012), Anderson et al. (2012), Trainer et al. (2012) have noted the importance of upwelled nutrients fueling blooms, but the role of subsurface populations in seeding surface blooms was rarely addressed. Yet, the evidence supporting the presence of subsurface seeding populations is increasing. Pseudo-Nitzschia dominated subsurface chlorophyll maximums (Ryan et al. 2005; Shipe et al. 2008) and thin layers have been observed along the
California coast (e.g., McManus et al. 2008; Churnside and Donaghay 2009). In Santa Monica Bay, California prior to a surface bloom, Pseudo-nitzschia dominated all depths except the surface five meters. However, two weeks later Pseudo-nitzschia dominated all depths with a maximum concentration at 20 meters that indicated the subsurface population could be particularly important (Shipe et al. 2008). Thin layers have been implicated as an explanation for the sudden appearance of a large HAB event as well as "cryptic blooms," toxicity without large increases in surface phytoplankton (Rines et al. 2002; McManus et al. 2008).

The cross-shelf subsurface transport of phytoplankton along shoaling isopycnals was demonstrated by the combined glider and ESP observations and has been shown in other studies to occur coastally in the SCB. Noble et al. (2009) completed a study in the San Pedro Channel showing cross-shelf transport of subthermocline water and dissolved and particulate materials including phytoplankton associated with shoaling internal tides. Lucas et al. (2011) in the SCB demonstrated potential effects of subsurface isopycnal tilt and thermal stratification on surface phytoplankton productivity, biomass, and community composition. Likewise, the offshore ESP detected a subsurface population of Pseudo-nitzschia that steadily increased in abundance along shoaling isopycnals prior to mixing with the nutrient-rich deep waters, suggesting that shoaling may relieve light limitation, possibly promoting increased subsurface phytoplankton growth.

An important role for the seeding of surface blooms by subsurface algal populations might also provide an explanation why nutrient-rich surface run-off events have not been strongly linked to Pseudo-nitzschia blooms along the southern California coast (Anderson et al. 2009; Schnetzer et al. 2013). Surface nutrients augmented by a storm event may support algae already present in surface waters, but would not trigger a Pseudo-nitzschia bloom if the population is located in deeper waters not directly coupled to the surface.

Anthropogenic inputs in the region could remain an important $\mathrm{HAB}$ variable although anthropogenic nutrient enrichment may not have directly initiated this Pseudo-nitzschia HAB events. Howard et al. (2014) showed that wastewater effluent could make a significant contribution to the total nitrogen in the San Pedro region and potentially these effluent derived nutrients could contribute to primary production when upwelled to surface waters. Anthropogenically influenced nutrient regimes can affect Pseudo-nitzschia HAB events in a variety of ways including shifting nutrient ratios and forms (e.g., nitrate, ammonia, or urea), that may sustain an event, shift the community species composition, or increase the toxicity of the cells (e.g., Kudela et al. 2008; Loureiro et al. 2009). Howard et al. (2007) have shown that some natural assemblages of Pseudo-nitzschia can double their DA content when utilizing urea, an indicator of eutrophication, as a nitrogen source as opposed to either nitrate 
or ammonium. Furthermore, anthropogenic nutrient enrichment modifies the nutrient ratios within an environment, and DA production is sensitive to shifting macronutrient ratios (Anderson et al. 2006).

The contribution of a seed population to nearshore surface blooms suggests that bloom development depends on an upwelling event but does not ensure that every upwelling event will lead to a bloom of Pseudo-nitzschia. A variety of factors can influence bloom establishment such as upwelling duration, intensity, frequency, subsurface population structure, and subsequent stratification of the water column. Upwelling duration will influence the nutrient concentrations and ratios injected into the surface waters. If the upwelling is too intense or persistent the subsurface populations could be pushed offshore resulting in no nearshore surface bloom. In the Santa Barbara Channel, Anderson et al. (2011) observed a decoupling of nearshore and offshore HAB events, which may be explained by prolonged upwellingdriven offshore transport of the phytoplankton. A combination of upwelling and relaxation events has been shown to be important in bloom establishment and the Pseudo-nitzschia bloom observed in this study resulted after an upwelling-relaxation-upwelling cycle comprised of a pair of two-day upwelling events separated by a five-day relaxation period. Wilkerson et al. (2006) demonstrated the importance of upwelling duration and relaxation along the California coast and found an optimal 3-7 day window of relaxed winds after an upwelling event to allow for chlorophyll accumulation. Velo-Suárez et al. (2010) showed the combination of upwelling and relaxing events can also be important to the formation and maintenance of thin layers that may serve as incubator for HABs. Therefore, a consideration of the duration of upwelling and the timing of a series of upwelling/relaxation sequences along with water column physical structure such as persistent stability could improve model success in predicting Pseudo-nitzschia bloom establishment and dynamics.

MODIS satellite remote sensing observations enabled the extrapolation of the glider observations to regions beyond the operational region of the gliders by providing synoptic snapshots of the near-surface ocean on larger space and longer temporal scales (Fig. 5). Satellites have been used to monitor the extent of HABs and satellite analysis is becoming an increasing popular method for detecting blooms along the California coast (Anderson, et al. 2009, 2011; Nezlin et al. 2012). Satellite ocean color imagery provides an estimate of ocean near-surface chlorophyll, which can indicate bloom occurrence. Combining glider data with satellite imagery provides a more complete resolution of the temporal and spatial history of HAB initiation and establishment. The offshore extent of the surface chlorophyll seen by the glider aligns well with the offshore extent observed by satellite imagery. Gliders are an effective way to expand the surface satellite imagery to observe subsurface phytoplankton populations and their variability. In situ subsurface measurements remain essential to fully understand the development and evolution of phytoplankton populations.

The combined approach of using multi-month in situ monitoring and high resolution remote sensing of SCB coastal blooms provided unique insight into the subsurface phytoplankton population seeding of a coastal surface Pseudo-nitzschia HAB event. Data integration and high frequency sampling greatly increase the ability to monitor bloom development. In situ genetic sampling by the moored ESPs verified the presences of a subsurface Pseudo-nitzschia population. The glider observations detailed the upwelling transport of deep nutrient-rich waters along with the subsurface phytoplankton communities, which resulted in a surface Pseudo-nitzschia bloom. These results revealed for the first time that upwelled subsurface phytoplankton populations can initiate surface $\mathrm{HAB}$ expressions in the region.

\section{References}

Anderson, C. R., M. A. Brzezinski, L. Washburn, and R. M. Kudela. 2006. Circulation and environmental conditions during a toxigenic Pseudo-nitzschia australis bloom in the Santa Barbara Channel, California. Mar. Ecol. Prog. Ser. 327: 119-133. doi:10.3354/meps327119

Anderson, D. M., A. D. Cembella, and G. M. Hallegraeff. 2012. Progress in understanding harmful algal blooms: Paradigm shifts and new technologies for research, monitoring, and management. Ann. Rev. Mar. Sci. 4: 143-176. doi:10.1146/annurev-marine-120308-081121

Anderson, C. R., D. A. Siegel, R. M. Kudela, and M. A. Brzezinski. 2009. Empirical models of toxigenic Pseudonitzschia blooms: Potential use as a remote detection tool in the Santa Barbara Channel. Harmful Algae 8: 478-492. doi:10.1016/j.hal.2008.10.005

Anderson, C. R., and others. 2011. Detecting toxic diatom blooms from ocean color and a regional ocean model. Geophys. Res. Lett. 38: L04603. doi:10.1029/ 2010GL045858

Armstrong, F. A. J., and E. C. LaFond. 1966. Chemical nutrient concentrations and their relationship to internal waves and turbidity off southern California. Limnol. Oceanogr. 11: 538-547. doi:10.4319/1o.1966.11.4.0538

Auro, M. E., and W. P. Cochlan. 2013. Nitrogen utilization and toxin production by two diatoms of the Pseudo-nitzschia pseudodelicatissima complex: P. cuspidata and $P$. fryxelliana. J. Phycol. 49: 156-169. doi:10.1111/jpy.12033

Cetinić, I., G. Toro-Farmer, M. Ragan, C. Oberg, and B. H. Jones. 2009. Calibration procedure for Slocum glider deployed optical instruments. Opt. Express. 17: 1542015430. doi:10.1364/OE.17.015420 
Churnside, J. H., P. L. Donaghay. 2009. Thin scattering layers observed by airborne lidar. ICES J. Mar. Sci. 66: 778-789. doi:10.1093/icesjms/fsp029

Crespo, B. G., F. G. Figueiras, and S. Groom. 2007. Role of across-shelf currents in the dynamics of harmful dinoflagellate blooms in the northwestern Iberian upwelling. Limnol. Oceanogr. 52: 2668-2678. doi:10.4319/ lo.2007.52.6.2668

Davis, R. E., M. D. Ohman, D. L. Rudnick, J. T. Sherman, and B. Hodges. 2008. Glider surveillance of physics and biology in the southern California current system. 53: 2151-2168. doi:10.4319/1o.2008.53.5_part_2.2151

Doucette, G. J., and others. 2009. Remote, subsurface detection of the algal toxin domoic acid onboard the Environmental Sample Processor: Assay development and field trials. Harmful Algae 8: 880-888. doi:10.1016/ j.hal.2009.04.006

Greenfield, D., R. Marin, III, S. Jensen, E. Massion, B. Roman, J. Feldman, C. A. Scholin. 2006. Application of environmental sample processor (ESP) methodology for quantifying Pseudo-nitzschia australis using ribosomal RNA-targeted probes in sandwich and fluorescent in situ hybridization formats. Limnol. Oceanogr. Methods 4: 426-435. doi:10.4319/lom.2006.4.426

Greenfield, D., and others. 2008. Field applications of the second-generation Environmental Sample Processor (ESP) for remote detection of harmful algae. Limnol. Oceanogr. Methods 6: 667-679. doi:10.4319/lom.2008.6.667

Hallegraeff, G. M. 1993. A review of harmful algal blooms and their apparent global increase. Phycologia. 32: 79-99. doi:10.2216/i0031-8884-32-2-79.1

Hillebrand, H., and U. Sommer. 1996. Nitrogenous nutrition of the potentially toxic diatom Pseudonitzschia pungens $f$. multiseries Hasle. J. Plankton Res. 18: 295-301. doi: 10.1093/plankt/18.2.295

Howard, M. D. A., N. Ladizinsky, W. P. Cochlan, and R. M. Kudela. 2007. Nitrogenous preference of toxigenic Pseudonitzschia australis (Bacillariophyceae) from field and laboratory experiments. Harmful Algae. 6: 206-217. doi: 10.1016/j.hal.2006.06.003

Howard, M. D. A., and others. 2014. Anthropogenic nutrient sources rival natural sources on small scales in the coastal waters of the Southern California Bight. Limnol. Oceanogr. 59: 285-297. doi:10.4319/1o.2014.59.1.0285

Janowitz, G. S., D. Kamykowski. 2006. Modeled Kareniabrevis accumulation in the vicinity of a coastal nutrient front. Mar. Ecol. Prog. Ser. 314:49-59. doi:10.3354/ meps314049

Kiefer, D. A. 1973. Fluorescence properties of natural phytoplankton populations. Mar. Biol. 22: 263-269. doi: 10.1007/BF00389180

Kudela, R. M., J. Q. Lane, and W. P. Cochlan. 2008. The potential role of anthropogenically derived nitrogen in the growth of harmful algae in California, USA. Harmful Algae 8: 103-110. doi:10.1016/j.hal.2008.08.019

Kudela, R., G. Pitcher, T. Probyn, F. Figueiras, T. Moita, and V. Trainer. 2005. Harmful algal blooms in coastal upwelling systems. Oceanography 18: 184-197. doi:10.5670/ oceanog.2005.53

Kudela, R. M., S. Seeyave, and W. P. Cochlan. 2010. The role of nutrients in regulation and promotion of harmful algal blooms in upwelling systems. Prog. Oceanogr. 85: 122135. doi:10.1016/j.pocean.2010.02.008

Lane, J. Q., P. T. Raimondi, and R. M. Kudela. 2009. Development of a logistic regression model for the prediction of toxigenic Pseudo-nitzschia blooms in Monterey Bay, California. Mar. Ecol. Prog. Ser. 383: 37-51. doi:10.3354/ meps07999

Lelong, A., H. Hegaret, P. Soudant, and S. S. Bates. 2012. Pseudo-nitzschia (Bacillariophyceae) species, domoic acid and amnesic shellfish poisoning: Revisiting previous paradigms. Phycologia 51: 168-216. doi:10.2216/11-37.1

Litaker, R. W., and others. 2008. Rapid enzyme-linked immunosorbent assay for the detection of the algal toxin domoic acid. J Shellfish Res. 27: 1301-1310. doi:10.2983/ 0730-8000-27.5.1301

Loureiro, S., C. Jauzein, E. Garces, Y. Collos, J. Camp, and D. Vaque. 2009. The significance of organic nutrients in the nutrition of Pseudo-nitzschia delicatissima (Bacillariophyceae). J. Plankton Res. 31: 399-410. doi:10.1093/plankt/ fbn 122

Lucas, A. J., C. L. Dupont, V. Tai, J. L. Largier, B. Palenik, and P. J. S. Franks. 2011. The green ribbon: Multiscale physical control of phytoplankton productivity and community structure over a narrow continental shelf. Limnol. Oceanogr. 56: 611-626. doi:10.4319/lo.2011.56.2.0611

MacFadyen, A., B. M. Hickey, and W. P. Cochlan. 2008. Influences of the Juan de Fuca Eddy on circulation, nutrients, and phytoplankton production in the northern California Current System. J. Geophys. Res. 113: C08008. doi:10.1029/2007JC004412

McManus, M. A., R. M. Kudela, M. W. Silver, G. F. Steward, P. L. Donaghay, and J. M. Sullivan. 2008. Cryptic blooms: Are thin layers the missing connection? Estuar. Coast. 31: 396-401. doi:10.1007/s12237-007-9025-4

Nezlin, N. P., M. A. Sutula, R. P. Stumpf, and A. Sengupta. 2012. Phytoplankton blooms detected by SeaWiFS along the central and southern California coast. J. Geophys. Res. 117: C07004. doi:10.1029/2011JC007773

Noble, M., B. Jones, P. Hamilton, J. Xu, G. Robertson, L. Rosenfeld, and J. Largier. 2009. Cross-shelf transport into nearshore waters due to shoaling internal tides in San Pedro Bay, CA. Cont. Shelf Res. 29: 1768-1785. doi: 10.1016/j.csr.2009.04.008

Pitcher, G., A. Boyd, D. Horstman, and B. Mitchell-Innes. 1998. Subsurface dinoflagellate populations, frontal blooms and the formation of red tide in the southern 
Benguela upwelling system. Mar. Ecol. Prog. Ser. 172: 253-264. doi:10.3354/meps172253

Pitcher, G. C., F. G. Figueiras, B. M. Hickey, and M. T. Moita. 2010. The physical oceanography of upwelling systems and the development of harmful algal blooms. Prog. Oceanogr. 85: 5-32. doi:10.1016/j.pocean.2010.02.002

Rines, J. E. B., P. L. Donaghay, M. M. Dekshenieks, J. M. Sullivan, and M. S. Twardowski. 2002. Thin layers and camouflage: Hidden Pseudo-nitzschia spp. (Bacillariophyceae) populations in a fjord in the San Juan Islands, Washington, USA. Mar. Ecol. Prog. Ser. 225: 123-137. doi: $10.3354 /$ meps 225123

Ryan, J., F. Chavez, and J. Bellingham. 2005. Physical-biological coupling in Monterey Bay, California: Topographic influences on phytoplankton ecology. Mar. Ecol. Prog. Ser. 287: 23-32. doi:10.3354/meps 287023

Schnetzer, A., and others. 2007. Blooms of Pseudo-nitzschia and domoic acid in the San Pedro Channel and Los Angeles harbor areas of the Southern California Bight, 2003-2004. Harmful Algae 6: 372-387. doi:10.1016/j.hal.2006.11.004

Schnetzer, A., and others. 2013. Coastal upwelling linked to toxic Pseudo-nitzschia australis blooms in Los Angeles coastal waters, 2005-2007. J. Plankton Res. 35: 10801092. doi:10.1093/plankt/fbt051

Scholin, C., and others. 1997. Detection and quantification of Pseudo-nitzschia australis in cultured and natural populations using LSU rRNA-targeted probes. Limnol. Oceanogr. 42: 1265-1272. doi:10.4319/1o.1997.42.5_part_2.1265

Seubert, E. L., and others. 2013. Seasonal and annual dynamics of harmful algae and algal toxins revealed through weekly monitoring at two coastal ocean sites off southern California, USA. Environ. Sci. Pollut. Res. Int. 20: 687895. doi:10.1007/s11356-012-1420-0

Shipe, R. F., A. Leinweber, and N. Gruber. 2008. Abiotic controls of potentially harmful algal blooms in Santa Monica Bay, California. Cont. Shelf Res. 28: 2584-2593. doi: 10.1016/j.csr.2008.08.003

Tilstone, G., B. Míguez, F. Figueiras, and E. Fermín. 2000. Diatom dynamics in a coastal ecosystem affected by upwelling: Coupling between species succession, circulation and biogeochemical processes. Mar. Ecol. Prog. Ser. 205: 23-41. doi:10.3354/meps 205023

Todd, R. E., D. L. Rudnick, R. E. Davis. 2009. Monitoring the greater San Pedro Bay region using autonomous underwater gliders during fall of 2006. J. Geophys. Res. 114: C06001. doi:10.1029/2008JC005086
Trainer, V. L., S. S. Bates, N. Lundholm, A. E. Thessen, W. P. Cochlan, N. G. Adams, and C. G. Trick. 2012. Pseudo-nitzschia physiological ecology, phylogeny, toxicity, monitoring and impacts on ecosystem health. Harmful Algae 14: 271-300. doi:10.1016/j.hal.2011.10.025

Trainer, V. L., B. M. Hickey, and R. A. Homer. 2002. Biological and physical dynamics of domoic acid production off the Washington coast. Limnol. Oceanogr. 47: 1438-1446. doi:10.4319/1o.2002.47.5.1438

Tyler, M. A, and H. H. Seliger. 1978. Annual subsurface transport of a red tide dinoflagellate to its bloom area: Water circulation patterns and organism distributions in the Chesapeake Bay. Limnol. Oceanogr, 23: 227-246. doi: 10.4319/1o.1978.23.2.0227

Velo-Suárez, L., L. Fernand and B. Reguera. 2010. Hydrodynamic conditions associated with the formation, maintenance and dissipation of a phytoplankton thin layer in a coastal upwelling system. Cont. Shelf Res. 30: 193-202. doi:10.1016/j.csr.2009.11.002

Wilkerson, F. P., and R. C. Dugdale. 1987. The use of large shipboard barrels and drifters to study the effects of coastal upwelling on phytoplankton dynamics. Limnol. Oceanogr. 32: 368-382. doi:10.4319/lo.1987.32.2.0368

Wilkerson, F. P., A. M. Lassiter, R. C. Dugdale, A. Marchi, and V. E. Hogue. 2006. The phytoplankton bloom response to wind events and upwelled nutrients during the CoOP WEST study. Deep Sea Res. II 53: 3023-3048. doi:10.1016/j.dsr2.2006.07.007

\section{Acknowledgments}

We thank the USC glider team for their support, especially M. Ragan, C. Oberg, B. Stauffer, G. Toro-Farmer, I. Cetinic, E. Teel, and X. Liu. Doug Hammond provided insightful discussions. Captain Ray Arntz and Sundiver crew ably provided support for glider deployments and recovery. Captain Jim Christman of the R/V Shana Rae, Scott Jensen, and volunteer divers from the Long Beach Aquarium of the Pacific assisted in the ESP deployment and recovery. The research was supported by NOAA ECOHAB grant NA11NOS4780052, California Sea Grant, NOAA Monitoring and Event Response for HABs (NA05NO54781228), California Ocean Protection Council (Grant Agreement 08-095), the State Water Resources Control Board (Agreement 08-060-250), and USC Sea Grant.

Received 10 July 2014 Accepted 15 December 2014 Amended 12 February 2015

Associate editor: David Antoine 